\title{
INITIAL TRAINING OF TEACHERS IN SCIENCE EDUCATION ACTIVITY: EXPLORING NON-FORMAL ENVIRONMENTS
}

\author{
Cecília Santiado do Carmo Araújo ${ }^{1}$ \\ Juliana Simião-Ferreira ${ }^{2}$ \\ Ruan Carlos Pires Faquim ${ }^{3}$ \\ Carollinny Vilas Boas dos Passos ${ }^{3}$ \\ Anna Claudia dos Santos ${ }^{4}$ \\ Herick Soares de Santana ${ }^{5}$ \\ Ramilla dos Santos Braga ${ }^{6}$ \\ Gislene Lisboa de Oliveira ${ }^{7}$
}

\begin{abstract}
Conceptions of Science influence educational practices and interpretations about the construction of scientific knowledge. Therefore, this study aimed to use scientific practice to test the efficiency of non-formal educational environments in training candidates for teacher certification in Biological Sciences. Training of candidates was performed in four meetings held on the State University of Goiás in Anápolis, which features an interpretative trail for environmental education. To test the hypothesis that the training was effective, a paired t-test was performed on the grades obtained in the questionnaires before and at the end of the activities (pretest and post-test). The test showed that the course was effective and led to an increase in students' knowledge of the content covered ( $\mathrm{t}$ test: $\mathrm{t}=2.95, \mathrm{df}=16, \mathrm{p}$ $=0.01)$, showing that on average, the scores of students increased in the post-test. This denotes a cognitive gain at the end of the course.
\end{abstract}

Keywords: Science education. Interpretative trails. Pre- and post-tests.

\footnotetext{
${ }^{1}$ Masters degree in Ecology and Evolution from the Federal University of Goiás(UFG), Inhumas, Goias, Brasil, cecilia.santiago.carmo@gmail.com.

2 Doctor in Ecology and Evolution at the Federal University of Goias and teacher at the Exact and Technological Sciences Unit(UEG), Quirinópolis, Goiás, Brasil, julianalimno@gmail.com.

${ }^{3}$ Masters students in Biological Diversity and Conservation in the Tropics at the Federal University of Alagoas, Laboratory of Ecology, Fish and Fisheries, LaEPP, Maceió, Alagoas. Brasil, ruan_faquim@hotmail.com, caroll_vilas@hotmail.com.

${ }^{4}$ Masters student in Ecology at the Federal University of Rio Grande do Norte, Department of Botany, Ecology and Zoology(DBEZ), Natal, Rio Grande do Norte, Brasil, anna.santos.ufrn@gmail.com

${ }^{5}$ Masters student in Ecology of Continental Aquatic Environments at the State University of Maringá, Biology Department - Center for Research in Limnology, Ichthyology and Aquaculture (NUPELIA), Maringá, Paraná, Brasil, herick.bio@gmail.com.

${ }^{6}$ Biologist degrees in Biological Sciences - Teacher Certification Module from the Exact and Technological Sciences Unit, Laboratory of Ecological Research and Science Education(UEG), Anápolis, Goiás, Brasil, ramillabraga@hotmail.com.

${ }^{7}$ Masters degree in Biology, teacher at the State University of Goiás - Unit of Distance Learning(UnUEAD), Anápolis, Goiás, Brasil, gislenelisboa@hotmail.com.
} 


\title{
FORMAÇÃO INICIAL DE PROFESSORES EM ATIVIDADE DE EDUCAÇÃO CIENTÍFICA: EXPLORANDO AMBIENTES NÃO FORMAIS DE EDUCAÇÃO
}

\begin{abstract}
Resumo: Concepções sobre Ciência influenciam práticas educacionais e interpretações sobre a construção do conhecimento científico. Assim, este trabalho objetivou utilizar a prática científica para testar a eficiência de ambientes não formais de educação na formação de acadêmicos de licenciatura em Ciências Biológicas. Para isto, foi realizada uma capacitação de acadêmicos em quatro encontros realizados no campus da Universidade Estadual de Goiás em Anápolis, que contém uma trilha interpretativa de educação ambiental. Para testar a hipótese de que a capacitação foi eficiente, foi realizado um teste $\mathrm{t}$ pareado entre as notas obtidas nos questionários aplicados antes e ao final das atividades (pré-teste e pós-teste). O teste mostrou que o curso foi eficiente e permitiu o aumento no conhecimento dos alunos sobre os conteúdos abordados (Teste $\mathrm{t}$ : $\mathrm{t}=2,95 ; \mathrm{g} .1 .=16 ; \mathrm{p}=0,01$ ), mostrando que, em média, as notas dos alunos aumentaram no pós-teste. Isto denota um ganho cognitivo ao final do curso.
\end{abstract}

Palavras-chave: Ensino de ciências. Trilhas interpretativas. Pré e pós-testes.

\section{FORMACIÓN INICIAL DE PROFESORES EN ACTIVIDAD DE EDUCACIÓN CIENTÍFICA: EXPLOTANDO AMBIENTES NO FORMALES DE EDUCACIÓN}

Resumen: Concepciones sobre Ciencia influyen las prácticas educacionales y las interpretaciones sobre la construcción del conocimiento científico. De este modo, este trabajo tuvo como objetivo utilizar la práctica científica para testar la eficiencia de ambientes no formales de educación en la formación de académicos de licenciatura en Ciencias Biológicas. Para esto, se realizó una capacitación de académicos en cuatro encuentros realizados en el campus de la Universidade Estadual de Goiás, en Anápolis, que tiene un sendero interpretativo de educación ambiental. Para testar la hipótesis de que la capacitación fue eficiente, se realizó un test pareado entre las notas obtenidas en los cuestionarios aplicados antes y al final de las actividades (pre y pos-test). El test mostró que el curso fue eficiente y permitió el aumento en el conocimiento de los alumnos sobre los contenidos abordados (Test $\mathrm{t}: \mathrm{t}=2,95 ; \mathrm{g} .1 .=16 ; \mathrm{p}=0,01)$, mostrando que, en promedio, las calificaciones de los alumnos aumentaron en el pos-test. Esto denota una ganancia cognitiva al final del curso.

Palabras clave: Enseñanza de ciencias. Senderos interpretativos. Pre y pos-tests. 


\section{Introduction}

The training of science and biology teachers seeks to enlarge the possibilities of work in the classroom, in order to promote the dissemination of science through the vast context of Science Education (PCN, 1997). In general, teachers present a vision of science compatible with empiricism, caused mainly by the indiscriminate use of mass media, which does not have a commitment to scientific training (CARVALHO, 2011) and this complicates the implementation of innovative educational practices. However, different conceptions of what is Science can positively influence educational practices, by interpreting how scientific knowledge is constructed, which has a commitment to rationality, i.e., with generalization, systematic coherence, experimental corroboration and reflective equilibrium (VILLANI, 2007).

Within this perspective, Science Education appears with the goal of making the study of science enjoyable and, at the same time, leads the learner (and citizen) to develop a scientific attitude towards, for example, the various environmental problems that exist. Such concepts are in accordance with the thinking of Freire (1996), reporting that the exercise of common sense is made through curiosity. In this sense, teaching methodologies are required which put into practice the ability of students to inquire, compare, doubt and evaluate learning aids in development of curiosity and a critical view. Therefore, the interpretation of quantitative and qualitative data in science classes can enrich the understanding of natural phenomena and processes and thus assist in environmental awareness (GATTI, 2004; MEDEIROS; BELLINI, 2001).

From the precepts of Science Education, education based on unilateral transfer of information, in which the teacher is the bearer of knowledge, has for a long time been proven ineffective. Better developed concepts of education show us that the student must climb steps building their own knowledge, from the experience of situations, so that the teacher is just the intercessor of this process (FREIRE, 1999). Thus, it is necessary that the teacher holds the position of researcher, being always updated and abreast of thoughtprovoking, didactic modalities to facilitate the understanding of basic concepts, so they can truly develop their skills and competences (KRASILCHIK, 1983; SILVA; CUNHA, 2012).

The construction of scientific knowledge can be done as in classrooms as in nonformal learning spaces. So, is important understand that these kind of spaces provides educational resources the conventional school does not have. These spaces have also the function to enhance the perception of the student to consider relevant information about the topic through processes and sharing experiences (GOHN, 2006). The use of nonformal environments in science classes enables an expansion of learning opportunities that are contrary to traditional education methods (PINTO; FIGUEIREDO, 2010; ARAUJO et al., 2011).

Non-formal education, practiced spontaneously in spaces that facilitate the learning process, encourages the students' curiosity about the new, giving the opportunity to understand the facts inherent in the everyday life situations. This enables students to enhance their learning, assuming that is acquired in the classroom can be applied and redeemed for various situations of day-by-day, enhancing the formation of this student as a critical citizen within society (GUIMARÃES; VASCONCELOS, 2006). In this way, museums, theaters, parks, plazas and trails can be cited as examples of this type of space (TILDEN, 1977; CURADO; ANGELINI, 2006).

The interpretive trails are activities carried out in natural environments, through the interpretation/explanation of a guide/monitor. This experience is an opportunity to come into contact with nature and learn about themselves, which can have meaning far beyond 
simple recreation and make them enjoyable opportunities for education, especially for children and adolescents (VASCONCELLOS, 1998). The activities carried out in nonformal educational environments, such as interpretive trails, can contribute to the promotion of Environmental Education, which has as a principal objective to support the training of a conscientious population concerned about the environment and associated issues (POOLEY; O'CONNOR, 2000). These processes must instigate students to analyze and participate in environmental issues, as well as stimulate a broad and critical perspective about the space. Thereby, such activities not only develop scientific knowledge, but also raise awareness which can prevent actions that degrade the environment (REIGOTA, 2009; BRASIL, 2011).

Teixeira, Tozoni-Reis and Talamoni (2011) and Peraya (1997) believe that critical environmental education paves the way for the suppression of media-centric educational practices (the traditional means of communication - auditory, written and visual - in isolation) and enables the conscious development of the individual, since it allows use of other teaching resources, such as the natural environment. This idea is consistent with Tozoni-Reis (2001), when he says that education using the natural environment has the function of reintegrating man in nature and, consequently, better adapting him to society.

In activities with this profile, a plethora of biological species can be used to promote understanding about different aspects of interpretative trails. Although vertebrates and plants are most often used in these activities, aquatic invertebrates have been noted for improving the readings on the environment (ANGELINI et al., 2011). Streams and rivers support communities that tell us the history of the site over a period of time greater than in terrestrial environments, where they are more prone to the climate.

A group that can be quite beneficial in these activities is the fauna of benthic macroinvertebrates (BIEGER et al., 2010), because it's a sensitive group to changes in their habitat and it be used in several studies to assess the environmental impacts (BIEGER et al., 2010; PAULA; FONSECA-GESSNER, 2010). Among these, aquatic insects are a dominant group and are very effective for the evaluation of adverse effects caused by anthropogenic activities on aquatic ecosystems (BAPTISTA, 2007; SASAKI et al., 2009) due to their ability to live and maintain high diversity in most aquatic systems, as well as their ability to colonize any kind of environment (MERRITT; CUMMINS, 1996; BONADA et al., 2006). In addition, these trophic organisms play a key role in energy flow and nutrient cycling in aquatic ecosystems (RUSSO et al., 2002; BISPO et al., 2006).Thus, it is possible to use this group of animals in practical educational activities in order to obtain quick and clear answers regarding the health of aquatic environments in the face of environmental changes caused by human activities. In addition, the use of quantitative and qualitative measurements for evaluation helps improve interpretations by making it easy to visualize the results. For this reason, the aim of this study was to use non-formal educational environments for the training of university-level biology students in activities of Science Education so that teachers in training can reflect on the use of non-formal learning environments as a tool for the promotion of Environmental Education by means of Science Education.

\section{Material and Methods}

\subsection{Study area}

The activities were carried out in an area of the campus of the State University of Goiás (UEG), in the city of Anápolis, Goiás. This area has three phytophysiognomic 
formations (cerrado, mesophilic forest and gallery forest), which are traversed by an EE interpretative trail called Tatu Trail (Figure 1) and an aquatic environment known as Barreiro Stream. The training of students in the Biological Science program took place in the Laboratory for Ecological Research and Science Education (LAB-PEEC), a location that receives students and teachers to develop diverse projects related to Scientific and Environmental Education. The students of Biological Sciences courses of several educational institutions were invited to participate in the course through various types of promotional materials (e-mails, flyers, posters and personal communication) distributed in several colleges of Anápolis, Goiás.

Figure 1 - Gateway to the Tatu Trail located in the area of Exact and Technological Sciences Unit (UnUCET) of the State University of Goiás (UEG) - Anápolis, Goiás

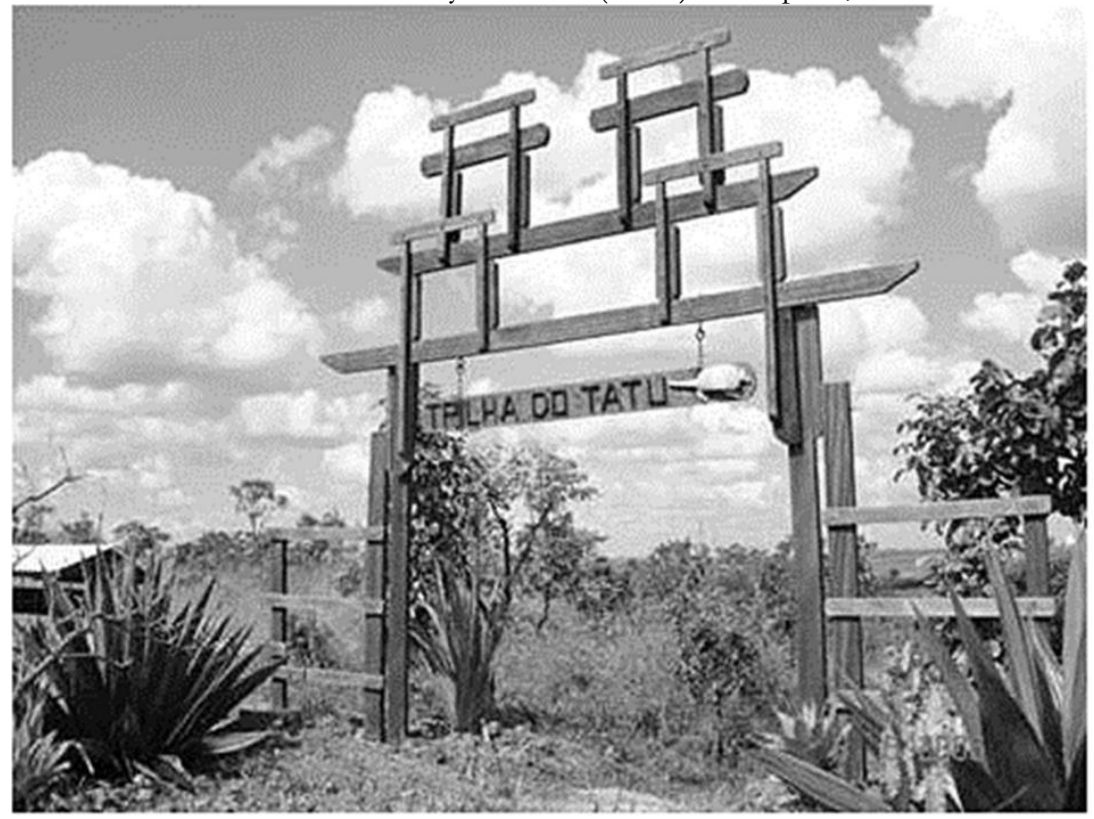

Fonte: Simião-Ferreira, 2011.

\subsection{Description of the activity}

A total of 57 students, from the $1^{\text {st }}$ to the $8^{\text {th }}$ period of the Biological Sciences course from several institutions of higher education in the city of Anápolis, participated in the training course offered by the Laboratory for Ecological Research and Science Education - UEG, however, only 17 attended four consecutive activities. At first, there was delivery of the material and an introductory class to present the content that would be covered during the course, the objectives, a description of activities and recognition of objects of study. The second meeting, entitled "Scientific Method for the Teaching of Science", presented in practice the steps of scientific research and how they can be used for teaching science. The third meeting, with the name of "Science education", discussed educational theories and practices related to scientific methods for the classroom. Finally, in the fourth and last meeting, students were told to present in groups a project that embraced the use of the scientific method in non-formal environments for teaching science. The steps are described in detail by their stage of realization.

\subsection{1. $\quad 1^{\text {st }}$ day: Introduction to the training course}

The participants answered to a questionnaire (pre-test) to test the hypothesis that the three science education activities, taken together, will promote a progressive increase in 
the understanding of content thought to the students of biology. The questionnaire had five objective questions about all the topics that would be discussed during the upcoming activities. Subsequently, an introduction to the course was given together with a spatial demonstration of the study area, emphasizing the Cerrado mosaic, the characteristics of the Barreiro Stream and the biodiversity of the area.

\subsection{2. $2^{\text {nd }}$ day: Field and laboratory activities}

In this activity, there were two modules. The first one corresponded to the field activity (walking the trail and collecting aquatic insects in the stream), while the second was the identification of aquatic insects and the interpretation of results. A new, pre-test questionnaire was answered, consisting of five questions about the topics of the day. The application of the questionnaire tested the hypothesis that students already have prior knowledge of the theoretical questions addressed.

Subsequently, the students were separated into groups and accompanied by two monitors on the walk down the Tatu Trail. The monitors were prepared in advance, which guarantees that the results do not suffer a bias due to the difference in the behavior of the monitor (ANGELINI et al., 2011). Each monitor was responsible for calling the attention of participants to information of the main features that make up each phytophysiognomy of the Cerrado of that region, in an attempt to simulate exactly what academics, as future teachers, should do with their students.

The route of the trail leads to Barreiro Stream, where students observed the procedures for collecting aquatic insects, made preliminary observations about the collected material and evaluated the physical environment around the collection point. Back in the lab, students began the work of taxonomically identifying the aquatic insects collected, with special emphasis on orders, as this taxonomic level of classification presents characteristics which are easily understood by students.

After the taxonomic identification of aquatic insects, the students were encouraged to analyze what was found in the collection and draw up charts and graphs with data of the richness and abundance, which served as a source for assessing the health of the stream, and thus identified the degree of anthropic impact to which the aquatic environment was submitted. In addition, they had a real opportunity to discuss, within the ecological standards, the possible mitigation measures of impacts found, such as alternatives for the preservation of the stream and of the species found therein. Shortly after the execution of all of the proposed plans for this day of activity, the students answered the same questionnaire from the beginning of the activity, now denominated post-test.

\subsection{3. $\quad 3^{\text {rd }}$ day: Science Education practices}

A new test was applied with questions about Science Education and then a lecture on theoretical aspects was presented, from the history of Science teaching in Brazil to specific aspects of scientific knowledge in the classroom. Then the monitors formed groups with a maximum of four students to develop and discuss ideas of Science Education projects that should be developed for the presentation in the following week (the fourth and last meeting). To end the day, the students responded to the post-test questionnaire.

\subsection{4. $4^{\text {th }}$ day: Completion of the training course}


In this last activity, a formal evaluation test was not performed. The groups presented projects to the monitors and other colleagues, such as activities that could be applied in schools for elementary and high school students. Validation of the activities proposed by each group depended on the applicability and feasibility of each project in schools and whether scientific methods were met. After the presentations and to complete the course, students responded to the same questionnaire as the first meeting.

The questionnaires application before and after each activity was performed to verify that the activity was effective based on whether students achieved higher grades after the activities. Furthermore, the application of the questionnaires before and after the training course aimed to verify whether the course contributed to the increase of knowledge of future teachers.

\section{Data Analyses}

To test the hypothesis that students had background knowledge of the theoretical issues addressed during each activity, a T-test was performed for dependent samples (or paired) (ZAR, 1996), using the grades of the pre- and post-tests taken during the activities. This test was intended to compare the grades of the same students before and after each activity.

To test whether the course using activities of SE was effective and promoted a progressive increase in the understanding of the content, a paired T-test was conducted between the grades earned on questionnaires on the first (pretest) and last (post-test) days of the course. For all tests, a significance level $(\alpha \leq)$ of $0.05 \%$ was used (ZAR, 1996).

In addition to the quantitative analysis, a qualitative analysis was performed of the activity and of the cognitive gain of biology students on the suggested method, using informal conversations with them to verify if the activity was valid for learning and whether they found the method applicable.

\section{Results and Discussion}

The course offered to students of Biological Sciences (Teacher Certification) for training in Science Education in non-formal Environments, using Ecological themes, contributed to the cognitive gain of the future teachers $(t=2.95$; d.f.. $=16 ; p=0.01)$, as can be observed in Table 1 and Figure 2. The results show that, on average, the students' scores increased after the activities, denoting a cognitive gain at the end of the course on Science Education, using the scientific method in non-formal environments, which highlights the importance of conducting such courses for teacher training.

Table 1 - Means, differences between the means and total number of students present in pre-and post-testing activities of Science Education conducted with students of Biology

\begin{tabular}{ccccc}
\hline Activities & Pre-test mean & Post-test mean & $\begin{array}{c}\text { Differences } \\
\text { between pre- } \\
\text { test and post- } \\
\text { test }\end{array}$ & $\begin{array}{c}\text { Total } \\
\text { students }\end{array}$ \\
\hline General & $2.18 \pm 1.01^{*}$ & $3.23 \pm 0.83^{*}$ & $-1.06 \pm 1.48$ & 17 \\
$\mathbf{2}^{\text {nd }}$ & $2.02 \pm 1.05^{*}$ & $2.41 \pm 0.99^{*}$ & $-0.39 \pm 1.02$ & 49 \\
$\mathbf{3}^{\text {rd }}$ & $3.60 \pm 0.98$ & $3.71 \pm 0.87$ & $-0.10 \pm 1.12$ & 48 \\
\hline
\end{tabular}

Note: $\mathrm{p}<0.05$ * Fonte: Carmo-Araújo, C.S., 2011. 
Figure 2 - Grades from the pre-and post-test questionnaires applied to General Biology students before and after the training course (T-test: $\mathrm{t}=2.95$, d.f. $=16, \mathrm{p}=0.01$ )

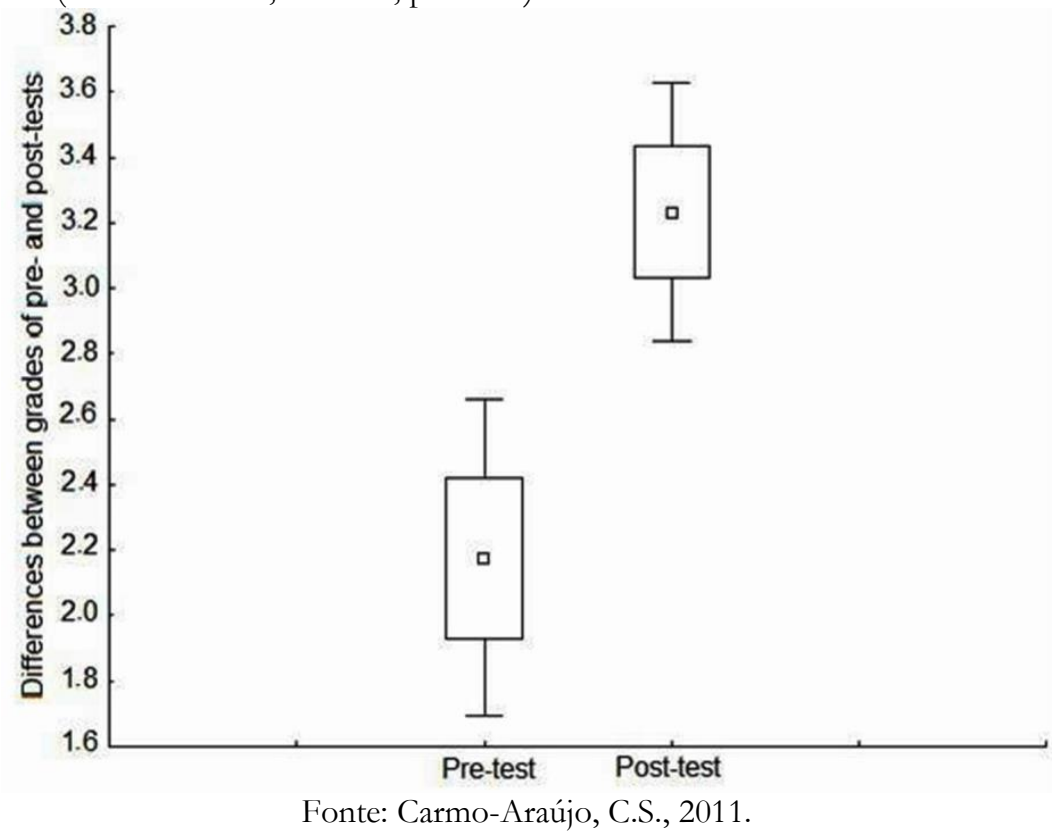

Non-formal environments allow internalization of content acquired from formal education, it can engage, interact and enable new experiences linking scientific knowledge with everyday (HIGUCHI; ZATTONI; BUENO, 2012). This methodology of teaching in non-formal environments, using the scientific method has been tested with elementary students. It was noted that an interpretative trail associated with laboratory activities, using the scientific method, can help children to approach scientific concepts and the conservation of biodiversity (ANGELINI et al., 2011). These authors also reinforce the results found by Curado and Angelini (2006), for which consecutive activities in Science and Environmental Education, carried out with students from elementary and high schools are more effective than activities performed only once. One-off activities bring only immediate cognitive gains and certainly weaken the effects generated by EE activities because, if students do not have continuous contact with that reality, the loss of the content is more pronounced (CURADO; ANGELINI, 2006).

The methodology chosen for this work is effective to train biology teachers to teach science education from non-formal environments such as the use of interpretive trail and identification of aquatic organisms. These activities can be understood as a tool of scientific discovery as it nears both students and teachers of reality in which they live, and the importance of preserving nature and the role of each one in his natural habitat. This type of educational methodology provides students understand that Science advances through new questions hypothesis that are answered by the steps of fundamental scientific research (PRAIA; GIL-PÉREZ; VILCHES, 2007). To take on the role of elementary students, the university students simulated execution of scientific and environmental activities during the course and realized that children will only learn effectively if they can explore and interact by themselves with the environment that surrounds them and actively participate in forming and building their knowledge (PIAGET, 1999). Education and learning is a relevant factor in the formation of the subject and should be continuous and lasting, perpetually occurring in the social, school and family life of the individual (VIEIRA; WEBER, 2002). It is through education, moreover, that we seek to raise 
awareness of the conservation and rational use of natural resources and the sustainability of the biodiversity of ecosystems (JACOBI, 2003).

The performance of students in the questionnaires applied on the second day was also improved after the development of the activity ( $\mathrm{T}$-test: $\mathrm{t}=2.67$; d.f. $=48 ; \mathrm{p}=0.01$; Table 1 and Figure 3). The grades on the post-test questionnaires were, on average, greater but did not reach a 0.5 point increase. On this day, all phases of the scientific method were used: observation, experimentation, elaboration of hypotheses, collection and data analysis and generalization of observed aspects (MOREIRA; OSTERMANN, 1993). The objective of these activities was to instigate students to think like a teacher, in order to encourage their students to develop scientific ideas in the classroom. The results showed that the second day provided knowledge gain, probably because all of the ecological and biological aspects, theoretical and practical, were new to the students.

Activities that prepare the attitude of biology teachers in and out of the classroom are necessary for them to improve their educational practices in order to provide a quality education. This is the first step for Science Education is truly crafted with students, demonstrating to students the steps of the scientific study.

Figure 3 - Grades from the pre- and post-test questionnaires applied to Biology students before and after the second day of activity in Science Education (T-test: $t=2.67$, d.f. $=48, \mathrm{p}=0.01$ )

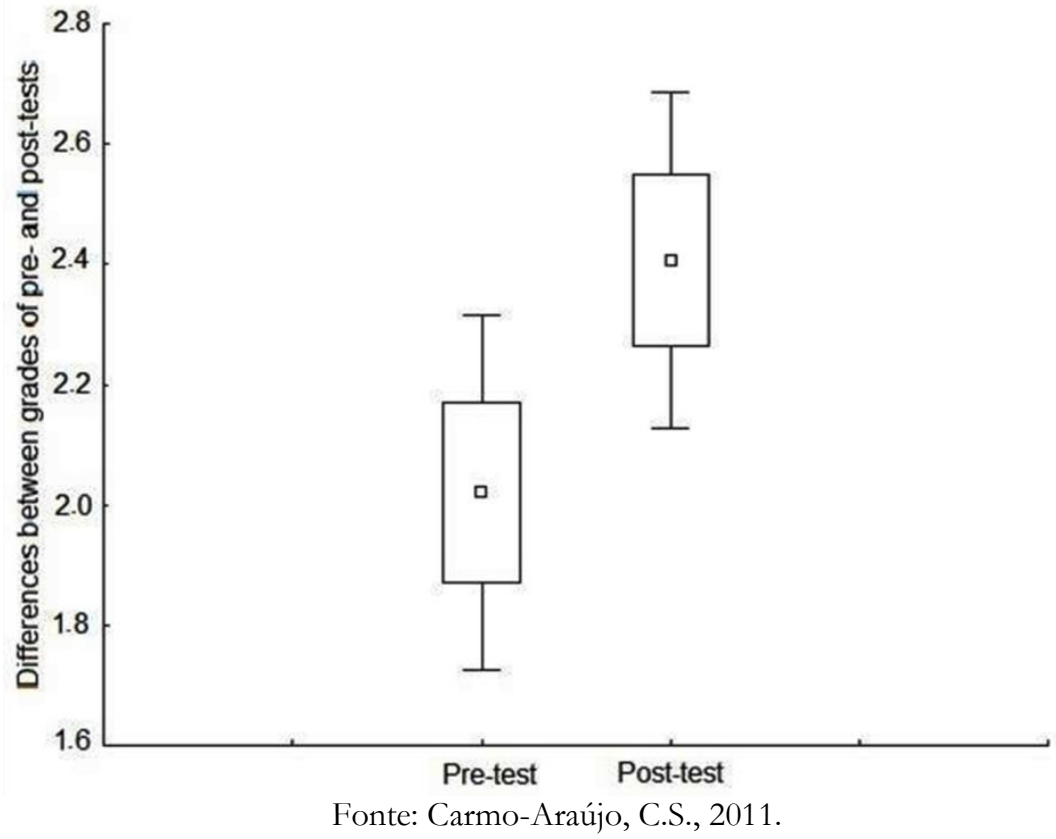

Contrary to what was found on the second day, the pupils' performance in pre- and post-test questionnaires on the third day of activity had low variation (T-test: $t=0.65$; d.f. $=$ 47; $\mathrm{p}=0.52$; Table 1 and Figure 4), showing that the discussion activity probably produced little increase in student learning. On this day, only education-related subjects were covered, such as Science Education in Brazil (BRASIL, 2008) and its detachment from scientific knowledge itself (CARVALHO-FILHO, 2006). Several discussions were also carried out about possible alternatives for improving the training of teachers and Science Education in the country. 
Figure 4 - Grades from the pre-and post-test questionnaires applied to Biology students before and after the third day of activity in Science Education (T-test: $\mathrm{t}=0.65$, d.f. $=47, \mathrm{p}=0.52$ )

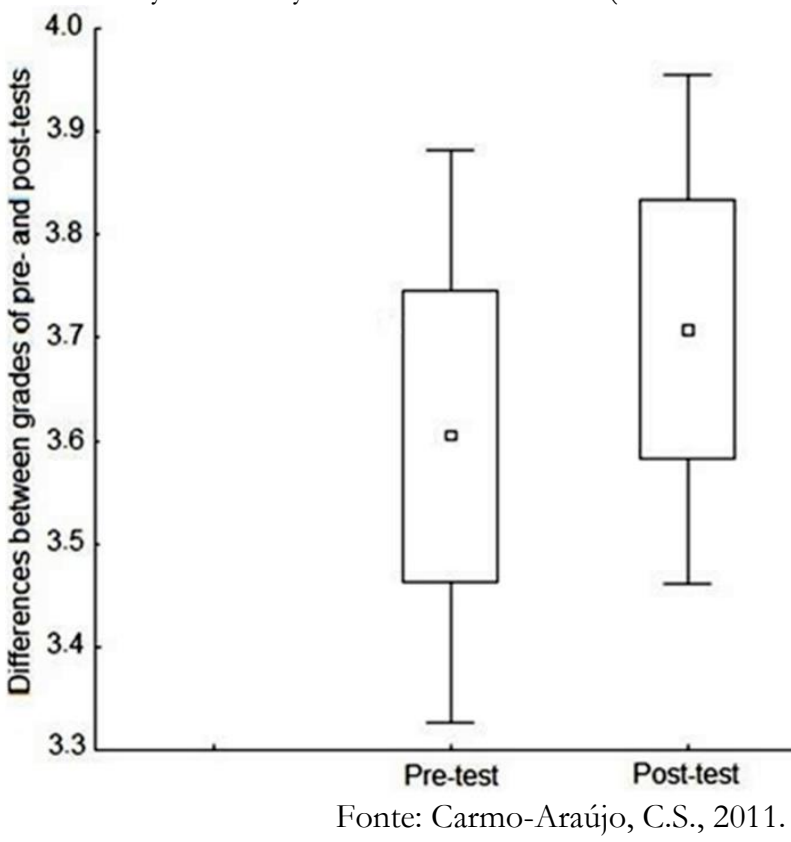

Even in teacher certification courses, topics targeted to education have caused considerable antipathy in recent years for most college students, due to disappointment related to the professional reality of the teacher. Students in teacher certification programs are increasingly frightened away by the reduction of resources for public education, low wages and the tragic reality of public schools nation-wide (HAMBURGER, 2007). Therefore, this is a possible explanation for the grades of the questionnaires remaining low after the activity.

On the last day, qualitative assessments were made in relation to the project presentations of the participants. The students presented projects produced by themselves, using this method of teaching science in other non-formal environments, and given before their colleagues and monitors. This audience, in turn, validated each project individually according to its feasibility in the classroom and theoretical, methodological and practical aspects. In all cases, the requirement was made that students consider in their projects the development of plans which focused on the use of the scientific method in non-formal environments. In this way, they all inspired their students to consider the actual environment by means of the elaboration of hypotheses and scientific investigations outside of the school environment.

Some groups demonstrated a full and clear understanding on how to address the scientific method in its activities, in addition to a good public presentation, while others had difficulties in the methodological part. However, overall, students showed understanding and managed to assimilate the importance of the choice of scientific method for teaching Science, which can assist in the understanding of environmental aspects and bring the students closer to the scientific world (MELO; VILLANI, 2011; LONGHINI; NARDI, 2007).

The real intention of the drafting of projects was to allow the students, in the posture of future teachers of General Science / Biology, to develop and replicate in the reality of the school what they saw and learned during the course of practical activities of Science Education, and to see that the method is applicable to any type of biological 
organism or phenomenon. Developing educational practices geared toward the discussion of issues related to the conservation and management of natural resources is today a necessity for developing better environmental awareness (PALHARES et al., 2000).

The laboratory that serves as the base for the study is inserted within the Cerrado biome, and therefore, the realization of activities of Science Education and Environmental Education in this area is extremely important for considering environmental issues. Additionally, such activities allow for a better understanding of the aspects of conservation and preservation of the species in this biome. This is very important as the Cerrado is considered a biodiversity "hotspot" (FURLEY; RATTER, 1988; MYERS et al., 2000; KLINK; MACHADO, 2005). Thus, activities that highlight conserving the biodiversity of this biome must be made so that the concepts of the students are not formed in an empiricist environment without scientific knowledge (CARVALHO-FILHO, 2006).

\section{Conclusions}

The training course is possibly effective in the continuous training process of students of Biological Sciences - Teacher Certification mode, who will be future teachers in regular schools. Successive activities in Science and Environmental Education courses probably provide better training of these professionals and have been demonstrated to be more effective in the process of formation of learning than one-off activities.

Any biological theme can be used in the development of these Environmental Education activities, and, taking into account that the main objective is the methodology in non-formal settings, they are ideal for good-quality professional training. Thus, the methods discussed in this paper are based on scientific methodological frameworks which can be applied to any area of education, whether in institutional environments or not, as well as being used in interdisciplinary contexts.

The use of non-formal educational environments (such as green areas, parks, forests, squares, museums, interpretive trails), or any environment that complements the classroom routine and traditional methodology of chalk-and-blackboard, has the potential to motivate student learning. Therefore, for this to happen with quality, creativity, and competence, knowledge of the best and most suitable methods of preparation of such classes is necessary to become these activities important. This makes practical courses in Science and Environmental Education mandatory for the training of competent and multifaceted professionals, because only in this way the teachers will fit in the current dynamic and demanding environment of Brazilian education.

\section{References}

ANGELINI, R.; SIMIÃO-FERREIRA, J.; CARMO-ARAÚJO, C.S.; CARVALHO. A. Effect of outdoor and laboratorial environmental science activities on middle school students' understanding on conservation. Naturez̧a \& Conservação, Goiânia, v. 9, n.1, p.1-5, Jul. 2011.

ARAUJO, E.S.N.N.; SOMAN, J.M.; CALUZI, J.J.; CALDEIRA, A.M.A. Ensino e aprendizagem de biologia em trilhas interpretativas: o modelo contextual do aprendizado como referencial. Revista Brasileira de Pesquisa em Educação em Ciências, São Paulo, v.11, n. 1, p. 31-56. 2011.

BAPTISTA, D.F.; BUSS, D.F.; EGLER, M.; GIOVANELLI, A.; SILVEIRA, M.P.; NESSIMIAN, J.L. A multimetric index based on benthic macroinvertebrates for evaluation of Atlantic Forest streams at Rio de Janeiro, Brazil. Hydrobiologia, Bruxelas, v. 575, n. 1, p. 83-94, Oct. 2007. 
BIEGER, L.; CARVALHO, ABP.; STRIEDER, M.N.; MALTCHIK, L.; STENERT, C. Are the streams of the Sinos River basin of good water quality? Aquatic macroinvertebrates may answer the question. Braz: J. Biol., São Carlos, v. 70, n. 4 (suppl), p.1207-1215, Dec. 2010.

BISPO, P.C.; OLIVEIRA, L.G.; BINI, L.M.; SOUZA, K.G. Ephemeroptera, Plecoptera and Trichoptera assemblages from riffles in mountain streams of Central Brazil: environmental factors influencing the distribution and abundance of immatures. Braz. J. Biol., São Carlos, v. 66, n. 2B, p. 611-622, May. 2006.

BONADA, N.; PRAT, N.; RESH, V.H.; STATZNER, B. Developments in Aquatic Insect Biomonitoring: a comparative analysis of recent approaches. Annu. Rev. Entomol., Califórnia, v. 51, p. 495-523, Aug. 2006.

BRASIL. Secretaria de Educação Fundamental. Parâmetros Curriculares Nacionais: meio ambiente. Brasília: MEC/SEF, 2011. Available at:

<http:/ / portal.mec.gov.br/seb/arquivos/pdf/meioambiente.pdf>. Accessed on: 06 May. 2011.

BRASIL. Secretaria de Educação Fundamental. Parâmetros Curriculares Nacionais: terceiro e quarto ciclos. Brasília: MEC/SEF, 2008. Available at:

<http://portal.mec.gov.br/seb/arquivos/pdf/ciencias.pdf>. Accessed on: 02 Jan. 2011.

BRASIL. Ministério da Educação. Secretaria de Educação Fundamental. Parâmetros Curriculares Nacionais. Brasília: MEC/SEE, 1997.

CARVALHO, W.L.P. A abordagem de questões sócio-científicas na formação de professores de biologia. Revista de la Facultad de Ciencia y Tecnologia, Misiones, v. Extra, p. 941-946. 2011.

CARVALHO-FILHO, J.E.C. Educação Científica na perspectiva Bachelardiana: ensino enquanto formação. São Paulo: Ensaio, 2006.

CURADO, P.M.; ANGELINI, R. Avaliação de atividade de Educação Ambiental em trilha interpretativa, dois a três anos após sua realização. Acta Scientiarum. Biological Sciences, Maringá, v. 28, n. 4, p. 395-401, oct./dec. 2006.

FREIRE, P. Pedagogia da Autonomia. 12 ed. Rio de Janeiro: Editora Paz e Terra, 1999.

FREIRE, P. Pedagogia da Autonomia: saberes necessários à prática educativa. São Paulo: Paz e Terra, 1996.

FURLEY, P.A.; RATTER, J.A. Soil resources and plant communities of central Brazilian cerrado and their development. Journal of Biogeography, London, v. 15, n. 1, p. 97-108, Jan. 1988.

GATTI, B.A. Estudos quantitativos em Educação. Educação e Pesquisa, São Paulo, v. 30, n. 1, p. 11 30, jan./abr. 2004.

GOHN, M.G. Educação não-formal, participação da sociedade civil e estruturas colegiadas nas escolas. Ensaios: Aval. Pol. Públ. Educ., Rio de Janeiro, v.14, n.50, p. 27-38, jan./mar. 2006.

GUIMARÃES, M.; VASCONCELLOS, M.M.N. Relação entre educação ambiental e educação em ciências na complementaridade dos espaços formais e não formais de educação. Educar, Curitiba, n. 27 , p. $147-162,2006$. 
HAMBURGER, E.W. Apontamentos sobre ensino de Ciências nas séries escolares iniciais. Estudos Avançados, São Paulo, v. 21, n. 60, p. 93-104, mai./jul. 2007.

HIGUCHI, M. I. G.; ZATTONI, M.; BUENO, F. P. Educação Ambiental em contextos não escolares: definindo, problematizando e exemplificando. Pesquisa em Educação Ambiental, Rio Claro, v. 7, n. 2, p. 119-131, 2012.

JACOBI, P. Educação Ambiental, cidadania e sustentabilidade. Cadernos de Pesquisa, São Paulo, v. 113, n. 118, p. 189-205, mar. 2003.

KLINK, C.A.; MACHADO, R.B. Conservation of the Brazilian Cerrado. Conservation Biology, Washington,v. 19, n. 3, p. 707-713, jun. 2005.

KRASILCHIK, M. Modalidades Didáticas. In: (Org.). Prática de ensino em biologia. 2 ed. São Paulo: Habra, 1983.

LONGHINI, M.D.; NARDI, R. A pesquisa sobre a prática como elemento na formação do professor: uma experiência envolvendo a formação inicial de professores de Física. Revista Eletrónica de Investigación en educación en ciencias, Tandil, v. 2, n. 1, p. 69-83, jan./jul. 2007.

MEDEIROS, M.G.L.; BELLINI, L.M. Educação Ambiental como Educação Cientificica: desafios para compreender ambientes sob impactos. Londrina: Editora UEL, 2001.

MELO, M.R.; VILLANI, A. A evolução de uma professora na formação de licenciados de química numa perspectiva sócio-ambiental. Investigações em Ensino de Ciências, Porto Alegre, v. 16, n. 2, p. 291 315, 2011.

MERRITT, R.W.; CUMMINS, K.W. An introducion to the aquatic insects of North America. 3ed. Duduque: Kendall \& Hunt, 1996.

MOREIRA, M.A.; OSTERMANN, F. Sobre o ensino do método científico. Cad. Cat. Ens. Fis, Florianópolis, v. 10, n. 2, p. 108-117,1993.

MYERS, N.; MITTERMEIER, R.A.; MITTERMEIER, C.G.; FONSECA, G.A.B.; KENT, J. Biodiversity hotspots for conservation priorities. Nature, London, v. 403, n. 6772, p. 853-858, Feb. 2000.

PALHARES, K.; MAYRINK, N.; MORENO, P.; GOULART, M.; MORETTI, M.; FERREIRA, W.; DINIZ, A.P.; RODRIGUES, L.; CALLISTO, M. Bioindicadores de qualidade de água: a educação ambiental como uma ferramenta de união UFMG - escolas. In: SIMPÓSIO DE ECOSSISTEMAS BRASILEIROS, 5, Vitória, 2000. Anais... Vitória: UFES, 2000. v.1, p. 182 -189.

PAULA, M.C.; FONSECA-GESSNER, A. A. Macroinvertebrates in low-order streams in two fragments of Atlantic Forest in different states of conservation, in the State of São Paulo (Brazil). Brą. J. Biol., São Paulo, v. 70, n. 3, p. 809-909, Oct. 2010.

PERAYA, D. As formas de comunicação pedagógica "midiatizada": o socioeducativo e o didático. Educação \& Sociedade, Campinas,v. 18, n. 59, p. 298-307, aug. 1997.

PIAGET, J. Genetic epistemology. In: DRIVER, R. et al. (Orgs.). Construindo o conhecimento cientifico na sala de aula. São Paulo: Química Nova na Escola, 1999. p. 31-40.

PINTO, L.T.; FIGUEIREDO, V.A. O ensino de Ciências e os espaços não formais de ensino. Um estudo sobre o ensino de Ciências no município de Duque de Caxias/RJ. In: SIMPÓSIO 
NACIONAL DE ENSINO DE CIÊNCIA E TECNOLOGIA, 2, Ponta Grossa, 2010. Anais... Ponta Grossa: UTFPR, 2010. v.7.

POOLEY, J.A.; O'CONNOR, M. Environmental education and attitudes: emotions and beliefs are what is needed. Environment and Behavior, London, v. 32, n. 5, p. 711-723, Sep. 2000.

PRAIA, J.; GIL-PÉREZ, D.; VILCHES, A. O papel da natureza da ciência na Educação para a cidadania. Ciência \& Educação, Bauru, v. 13, n. 2, p-141-156. aug/dec. 2007.

REIGOTA, M. O que é educação ambiental? 2ed. São Paulo: Brasiliense, 2009.

RUSSO, M.R.; FERREIRA, A.; DIAS, R.M. Disponibilidade de invertebrados aquáticos para peixes bentófagos de dois riachos da bacia do rio Iguaçu, Estado do Paraná, Brasil. Acta Scientiarum, Maringá, v. 24, n. 2, p. 411-417, 2002.

SASAKI, T.; OKUBO, S.; OKAYASU, T.; JAMSRAN, U.; OHKURO, T.; TAKEUCHI, K. Management applicability of the intermediate disturbance hypothesis across Mongolian rangeland ecosystem. Ecological Applications, New York, v. 19, n. 2, p.423-432, mar. 2009.

SILVA, F.; CUNHA, A.M. Método científico e prática docente: as representações sociais de professores de ciências do ensino fundamental. Ciência \& Educação, Bauru, v.18, n.1, p.41-54, jan/jul. 2012.

TEIXEIRA, L.A.; TOZONI-REIS, M.F.C.; TALAMONI, J.L.B. A teoria, a prática, o professor e a educação ambiental: algumas reflexões. Olhar de Professor, Campinas, v. 14, n. 2, p.223-237, jul./dec. 2011.

TILDEN, F. Interpreting our Heritage. Chapel Hill: The University of North Carolina Press, 1977.

TOZONI-REIS, M.F.C. Educação Ambiental: referências teóricas no ensino superior. Interface. Comunicação, Saúde e Educação, Botucatu, v. 5, n. 9, p. 132-143, ago. 2001.

VASCONCELlOS, J.M.O. Avaliação Da Visitação Pública e da Eficiência de Diferentes Tipos de Trilhas Interpretativas no Parque Estadual Pico do Marumbi e Reserva Natural Salto Morato - PR. 1998. $163 f$.

Thesis (Doctorate in Forest Science) - Universidade Federal do Paraná, Curitiba, 1998. Available at: <http://dspace.c3sl.ufpr.br:8080/dspace/handle/1884/25417>. Accessed on: 15 Oct. 2012.

VIEIRA, P.F.; WEBER, J. Gestão de Recursos Naturais Renováveis e Desenvolvimento. São Paulo: Cortez, 2002.

VILLANI, A. Uma contribuição da filosofia de ciências para a educação em ciências. In: BORGES, R.M.R. (Org.). Filosofia e História da Ciência no contexto da Educação em Ciências: vivências e teorias. Porto Alegre: EDIPUCRS, 2007.

ZAR, J.H. Biostatistical Analysis. Prentice Hall: Editora Prentice Hall, 1996.

\section{Aknowledgements}

To the professors Dr. Hélida Ferreira Cunha and Dr. Samantha Solomão Caramori for making the Laboratory for Ecological Research and Science Education (LAB-PEEC), for which they are responsible, available for the realization of this study. To the colleagues who participated in lab activities and allowed this work was done. 
Pesquisa em Educação Ambiental, vol. 8, n. 2 - pp 97-110 , 2013

Artigo submetido em 19/06/2013

Artigo aprovado em 29/11/2013 